\title{
The importance of the linkage between national and international research funders to support malaria elimination
}

Hassan Mshinda

From Challenges in malaria research

Basel, Switzerland. 10-12 October 2012

Abstract not submitted

Published: 15 October 2012

doi:10.1186/1475-2875-11-S1-O4

Cite this article as: Mshinda: The importance of the linkage between

national and international research funders to support malaria

elimination. Malaria Journal 2012 11(Suppl 1):04.

Submit your next manuscript to BioMed Central and take full advantage of:

- Convenient online submission

- Thorough peer review

- No space constraints or color figure charges

- Immediate publication on acceptance

- Inclusion in PubMed, CAS, Scopus and Google Scholar

- Research which is freely available for redistribution 